\title{
TINJAUAN YURIDIS TERHADAP PASAL 11 AYAT (1) PERATURAN DAERAH SURAKARTA NO.10 TAHUN 2015 TENTANG PERLINDUNGAN DAN PENGELOLAAN LINGKUNGAN HIDUP DI SURAKARTA
}

\author{
Gunadi Rachmad Widodo \\ Ma'mun Efendi Nur \\ Universitas Nahdlatul Ulama Surakarta
}

\begin{abstract}
Abstrak
Penelitian ini bertujuan untuk mengetahui pelaksanaan pembentukan Peraturan Daerah Surakarta No. 10 Tahun 2015 Tentang Perlindungan dan Pengelolaan Lingkungan Hidup di Surakarta. Penelitian menggunakan pendekatan normatif atau kepustakaan. Hasil penelitian menunjukkan bahwa Pelaksanaan pembentukan Peraturan Daerah Surakarta No. 10 Tahun 2015 Tentang Perlindungan dan Pengelolaan Lingkungan Hidup di Surakarta, telah sesuai dengan peraturan undang-undang yang berlaku di Negara Kesatuan Republik Indonesia. Kelebihan yaitu; sangat membantu Pemerintah Kota Surakarta dalam melestarikan fungsi lingkungan hidup, dan mempunyai kelemahan yaitu; bahwa pasal ini dalam penjelasannya belum ada tentang penanggung jawab jenis kegiatan atau usaha yang mana yang wajib mengolah limbah cairnya, karena ternyata penanggung jawab kegiatan atau usaha yang berbadan hukum lah yang wajib mengolah air limbahnya sendiri.
\end{abstract}

Kata kunci: Peraturan Daerah, Lingkungan Hidup

\section{Abstract}

This research aims to find out the implementation of Surakarta Regional Regulation No.10 of 2015 on Environmental Protection and Management in Surakarta. The study uses normative, or library approaches. The results 
showed that the establishment of Surakarta Regional Regulation No. 10 of 2015 concerning Environmental Protection and Management in Surakarta has been following the regulations of the law applicable in the Unitary State of the Republic of Indonesia. Advantages are; Beneficial to the Surakarta City Government in preserving the function of the environment, and has weaknesses, namely; that this article in its explanation does not yet exist about the person in charge of which type of activity or business is obliged to treat liquid waste, because it turns out that the person in charge of activities or interactions that are legal entities are obliged to treat their wastewater.

Keywords: Local Regulations, Environment

\section{A. PENDAhULUAN}

Melihat kembali UUD 1945 Bab XIV Tentang Perekonomian Nasional dan Kesejahteraan Sosial, menerangkan bahwa negara menjamin kepada setiap warga negara mengenai kesejahteraannya yaitu pada pasal 33 ayat (4): Perekonomian nasional diselenggarakan berdasar atas demokrasi ekonomi dengan prinsip kebersamaan, efisiensi, berkeadilan, berkelanjutan, berwawasan lingkungan, kemandirian, serta dengan menjaga ke-seimbangan kemajuan dan kesatuan ekonomi nasional. Berwawasan lingkungan adalah upaya sadar dan berencana menggunakan dan mengelola sumber daya secara bijaksana dalam pembangunan yang terencana dan berkesinambungan untuk meningkatkan mutu hidup.'

Dengan melihat pasal diatas maka perekonomian nasional yang di selenggarakan oleh negara maupun swasta harus berwawasan lingkungan, ini artinya bahwa salah satu hal penting yang berkaitan dengan faktor peningkatan perekonomian nasional berupa produksi apapun, tidak boleh mengesampingkan faktor kelestarian lingkungan. Lingkungan hidup yang baik dan sehat merupakan salah satu hak asasi yang dimiliki oleh setiap manusia, maka perlu terus dijaga kualitasnya agar tetap dapat menunjang pembangunan berkelanjutan yaitu; proses pembangunan (lahan, kota, bisnis, masyarakat, dsb) yang berprinsip untuk memenuhi kebutuhan sekarang tanpa

\footnotetext{
${ }^{1}$ Wijat Subagia, http://wijatsubagia.blogspot.co.id/2013/06/normal-0-false-false-false-in-x-nonex.html. Jum'at, 13 Oktober 2018, 09:40.
} 
mengorbankan pemenuhan kebutuhan generasi masa depan.2

Aktivitas disegala bidang di Kota Surakarta berpotensi terhadap pencemaran lingkungan hidup, sehingga perencanaan, pemanfaatan, pengendalian, pemeliharaan, pengawasan dan penegakan hukum merupakan komponen penting dalam pelaksanaan perlindungan dan pengelolaan lingkungan hidup.

Untuk melaksanakan ketentuan Pasal 63 ayat (3) Undang-undang Nomor 32 Tahun 2009 Tentang Perlindungan dan Pengelolaan Lingkungan Hidup, maka untuk memberikan kepastian hukum dalam pelestarian fungsi lingkungan hidup yaitu; rangkaian upaya untuk memelihara kelangsungan daya dukung dan daya tampung lingkungan ${ }^{3}$ di Kota Surakarta, perlu landasan yang kuat Tentang Perlindungan dan Pengelolaan lingkungan hidup dalam suatu Peraturan Daerah Kota Surakarta Tentang Perlindungan dan Pengelolaan Lingkungan Hidup. Dalam Peraturan daerah ini diatur tentang: Perencanaan Perlindungan dan Pengelolaan Lingkungan Hidup, Pemanfaatan Sumber Daya Alam dan Lingkungan Hidup di daerah, Pengendalian dan Pencegahan Pencemaran dan/atau Kerusakan Lingkungan Hidup, Pemulihan Fungsi Lingkungan Hidup, Pemeliharaan Lingkungan Hidup, Pengawasan, serta Penegakan Hukum.

Faktor perekonomian nasional berkembang pesat akhir-akhir ini, termasuk di wilayah Surakarta dan sekitarnya, yaitu dilihat dari berdirinya usaha-usaha yang bergerak dalam bidang pangan, sandang, papan, kesehatan, pariwisata dan masih banyak lainnya. Hal ini berdampak baik pada meningkatnya kesejahteraan masyarakat di sekitar Surakarta pada umumnya, tetapi dampak baik tersebut pasti diikuti oleh dampak buruk yang timbul dari berdirinya usaha-usaha yang bergerak dalam bidang pangan, sandang, papan, kesehatan, pariwisata dan lainnya.

Setiap bidang usaha di Wilayah Surakarta khususnya pasti akan menghasilkan limbah yaitu; sisa suatu usaha dan/ atau kegiatan. ${ }^{4}$ Limbah beberapa diantaranya termasuk dalam kategori limbah Bahan Beracun dan Berbahaya yaitu; sisa suatu usaha dan/ atau kegiatan yang mengandung

\footnotetext{
${ }^{2}$ https://id.wikipedia.org/wiki/Pembangunan berkelanjutan, Jum'at, 13 Oktober 2018, 09:45.

3 Peraturan Daerah Surakarta No. 10 Tahun 2015, Tentang Perlindungan Dan Pengelolaan Lingkungan Hidup, Hal 4.

${ }^{4}$ Peraturan Pemerintah No. 101 Tahun 2014 Tentang Pengelolaan Limbah Bahan Berbahaya Dan Beracun. Hal 2.
} 
Bahan Beracun dan Berbahayas, yang apabila tidak dikelola dengan baik maka akan merusak kelestarian lingkungan sekitarnya, bahkan bila terkumulasi selama bertahun-tahun akan menimbulkan bahaya terhadap ekosistem yaitu; kesatuan komunitas dan lingkungan hidup yang saling berinteraksi dan membentuk hubungan timbal balik ${ }^{6}$. Faktor kelestarian lingkungan harus terus dijaga dari kerusakan yang diakibatkan salah satunya oleh limbah yang dihasilkan perusahaan-perusahaan pemerintah maupun swasta khususnya di Surakarta.

Untuk memberikan kepastian hukum dalam pelestarian fungsi lingkungan hidup di Kota Surakarta tersebut maka dibuatlah Peraturan Daerah Surakarta No.10 Tahun 2015 Tentang Perlindungan dan Pengelolaan Lingkungan Hidup. Salah satu jenis limbah B3 yang di hasilkan oleh perusahaan-perusahaan tersebut adalah limbah cair yang aturannya tertuang pada pasal 11 ayat (1) Peraturan Daerah Surakarta No.10 Tahun 2015 Tentang Perlindungan dan Pengelolaan Lingkungan Hidup.

Pemerintah Daerah menurut Undang-undang Republik Indonesia No: 23 Tentang Pemerintah Daerah Pasal 1 Ayat (2) yaitu; penyelenggara urusan pemerintahan oleh pemerintah daerah dan dewan perwakilan rakyat daerah menurut asas otonomi dan tugas pembantuan dengan prinsip otonomi seluas-luasnya dalam sistem dan prinsip Negara Kesatuan Republik Indonesia sebagaimana dimaksud dalam Undang-undang Dasar Negara Republik Indonesia Tahun 1945.

Didalam pemerintahan daerah, kepala daerah sebagai unsur penyelenggara Pemerintahan Daerah yang memimpin pelaksanaan urusan pemerintahan yang menjadi kewenangan daerah otonom serta Dewan Perwakilan Rakyat Daerah yang selanjutnya disingkat DPRD adalah lembaga perwakilan rakyat daerah yang berkedudukan sebagai unsur penyelenggara pemerintahan daerah yang mempunyai hak, wewenang dan kewajiban daerah otonom untuk mengatur dan mengurus sendiri urusan pemerintahan dan kepentingan masyarakat setempat dalam sistem Negara

\section{${ }^{5}$ Ibid.}

\footnotetext{
Maulana Sidik, "Buku Ekosistem Untuk Umum", https://maulanasidik05.wordpress.com/2015/01/09/buku-ekosistem-untuk-umum/. Hal.3. Kamis, 12 Oktober 2018, 13.00.

${ }^{7}$ Undang-Undang Republik Indonesia Nomor 23 Tahun 2014 Tentang Pemerintahan Daerah, Hal.2.
} 
Kesatuan Republik Indonesia.

Peraturan Daerah Kabupaten/ Kota adalah Peraturan PerundangUndangan yang dibentuk oleh Dewan Perwakilan Rakyat Daerah Kabupaten/ Kota dengan persetujuan bersama Bupati/ Walikota, berdasarkan pengertian peraturan daerah tersebut, jelas menyebutkan bahwa kedudukan DPRD, baik di tingkat provinsi maupun di Kabupaten dan kota jelas merupakan lembaga menjalankan kekuasaan legislatif di daerah. Di samping itu, pengisian jabatan keanggotaannya juga dilakukan melalui pemilihan umum. Baik DPRD maupun Kepala Daerah, yaitu Gubernur, Bupati, dan Walikota sama-sama dipilih langsung oleh rakyat. Keduanya lembaga legislatif dan eksekutif, sama-sama dipilih langsung oleh rakyat, dan sama-sama terlibat dalam proses pembentukan suatu Peraturan Daerah. Karena itu, seperti halnya Undang-undang di tingkat pusat, Peraturan Daerah dapat dikatakan juga merupakan produk legislatif di tingkat daerah yang bersangkutan, dan tidak disebut sebagai produk regulatif atau executive acts.

Disusunnya Badan-Badan Perwakilan di daerah bukan untuk menyusun dan membentuk ataupun mendirikan negara baru atau merubah Undang-undang Dasar 1945 baik sebagian maupun keseluruhan, melainkan untuk menegakan, mempertahankan, mengamalkan dan mengamankan Pancasila dan UUD 1945 serta melaksanakan demokrasi.' Adanya pembentukan DPRD di daerah dapat pula dikatakan sebagai adanya suatu perwujudan dari pasal 18 Undang-undang Dasar 1945 yang mana diatur lebih lanjut dalam Undang-undang Nomor 23 Tahun 2014 Tentang Pemerintahan Daerah yang mana lebih menekankan pentingnya otonomi daerah dalam rangka pemerataan pembangunan nasional. Hal ini didasarkan pada suatu asumsi yang mana masyarakat daerah yang bersangkutanlah yang lebih mengetahui dinamika daerahnya sendiri.

Pembentukan peraturan daerah itu merupakan suatu pekerjaan yang sulit, karena dituntut kesempurnaan seperti dalam hal sistematis, tatanan bahasa, istilah dan juga banyaknya berbagai jenis materi yang akan diatur sesuai dengan kebutuhan. Suatu peraturan yang baik dalam persiapan pembuatannya membutuhkan pengetahuan mendalam dari materi yang akan

\footnotetext{
${ }^{8}$ Jimly Assiddiqqie, Hukum Acara Pengujian Undang-Undang, (Jakarta: Konstitusi Pers, 2006), hal. 32-33.

${ }^{9}$ Kansil, C.S.T,.Pokok-Pokok Pemerintahan Daerah, (Jakarta : Aksara Baru,1979), hal. 12.
} 
diatur, memiliki kemampuan untuk menemukan inti dari fakta-fakta yang sudah tumbuh sejak lama serta mengungkap ke dalam bentuk peraturan yang singkat dan dengan bahasa yang jelas.

Wewenang dalam membuat peraturan daerah terdapat pada eksekutif/ Kepala Daerah dan legislatif/ DPRD. Dimana masing-masing badan baik eksekutif maupun legislatif berhak mengajukan rancangan peraturan daerah ,dan dalam hal penetapan peraturan daerah kepala daerah harus mendapat persetujuan dari DPRD. Peraturan daerah memiliki karakteristik yang sifatnya mengatur, yakni mengatur hubungan antara pemerintah daerah, masyarakat dan stake hoder local seperti dunia usaha. Peraturan daerah bukan hanya mengatur hal-hal yang menyangkut atau berhubungan dengan kehidupan politik, sosial dan budaya masyarakat. Daerah Kabupaten/ Kota di Indonesia sangatlah banyak, yang memiliki keanekaragaman budaya, adat istiadat yang berbeda. Peran Pemerintah Daerah sangatlah penting dalam mengatur masyarakatnya, oleh karena itu dalam pembuatan Peraturan Daerah harus menyesuaikan dengan kondisi masyarakatnya yang cenderung dinamis.

Setiap jenis peraturan perundang-undangan tersebut di atas memiliki fungsi, tujuan, teknik pembentukan yang berbeda-beda, karena dalam pemakaiannya itu pun berbeda. Salah satunya adalah Peraturan Daerah Kabupaten/ Kota Dalam Tata Urutan Perundangan Indonesia terdapat Peraturan Daerah (Perda) dan Proses Penyusunan Peraturan Daerah melalui tahapan sebagai berikut:

\section{Tahapan Pengajuan Peraturan Daerah (Perda)}

Pada tahap ini, pengajuan rancangan peraturan daerah dapat dilakukan oleh Pemerintah Daerah maupun oleh DPRD. Pengajuan Rancangan Perda oleh Kepala Daerah Proses pengajuan rancangan peraturan daerah dari kepala daerah adalah sebagai berikut:

a. Konsep rancangan peraturan daerah disusun oleh dinas yang berkaitan dengan Perda yang dibuat.

b. Konsep rancangan Perda yang telah disusun diajukan kepada biro hukum untuk dilakukan pemeriksaan secara teknis. 
c. Biro hukum selanjutnya mengundang dinas yang mengajukan rancangan Perda untuk melakukan penyempurnaan konsep rancangan Perda yang bersangkutan.

d. Biro hukum menyerahkan hasil penyempurnaan rancangan Perda kepada kepala daerah untuk disetujuinya.

e. Konsep rancangan Perda yang telah disetujui oleh kepala daerah berubah menjadi rancangan peraturan daerah.

f. Rancangan peraturan daerah kemudian oleh kepala daerah disampaikan kepada ketua DPRD yang disertai dengan surat pengantar untuk memperoleh persetujuan dari DPRD.

2. Pengajuan Rancangan Peraturan Daerah oleh DPRD, proses pengajuan Rancangan Peraturan Daerah oleh DPRD adalah sebagai berikut:

a. Usulan rancangan peraturan daerah dapat diajukan oleh sekurangkurangnya lima anggota DPRD.

b. Usulan rancangan peraturan daerah tersebut disampaikan kepada pimpinan DPRD untuk dibahas dalam sidang paripurna DPRD.

c. Pembahasan usulan rancangan peraturan daerah dalam sidang paripurna DPRD dilakukan oleh anggota DPRD bersama kepala daerah.

3. Tahap Pembahasan dalam Sidang DPRD, setelah proses pengajuan tersebut di atas, akan dilakukan pembahasan rancangan peraturan daerah melalui empat tahap sebagai berikut:

a. Tahap Pertama

Pada tahap ini dilakukan pembahasan rancangan peraturan daerah dalam sidang paripurna DPRD. Rancangan Perda yang datang dari kepala daerah, penyampaiannya dilakukan oleh kepala daerah, sedang yang datang dari DPRD penyampaiannya dilakukan oleh pimpinan gabungan komisi.

\section{b. Tahap Kedua}

Pada tahap ini adalah acara pemandangan umum. Pemandangan umum tentang rancangan Perda yang datang dari kepala daerah dilakukan oleh anggota fraksi, dan kepala daerah yang memberikan jawaban atas 
pemandangan umum tersebut. Sebaliknya, untuk rancangan Perda dari DPRD, pemandangan umum disampaikan oleh kepala daerah, dan DPRD memberikan jawaban atas pendapat kepala daerah.

c. Tahap Ketiga.

Pada tahap ini adalah kegiatan rapat komisi atau gabungan komisi yang dihadiri oleh kepala daerah. Tujuan dalam kegiatan rapat ini adalah memperoleh kesepakatan tentang rancangan Perda antara kepala daerah dan DPRD.

d. Tahap Keempat.

Kegiatan dalam tahap keempat adalah sidang paripurna untuk mengambil keputusan dan persetujuan DPRD atas rancangan Perda. Setelah diputuskan dan disetujui, maka rancangan Perda ditetapkan dan ditanda tangani oleh kepala daerah dan DPRD. Kemudian dilanjutkan dengan pengumuman peraturan daerah pada lembaran daerah. ${ }^{10}$

Bahwa didalam Undang-undang Republik Indonesia Nomor 12 Tahun 2011 tentang Pembentukan Peraturan Perundang-undangan, Menimbang, Huruf b yaitu: untuk memenuhi kebutuhan masyarakat atas peraturan perundang-undangan yang baik, perlu dibuat peraturan mengenai pembentukan peraturan perundang-undangan yang dilaksanakan dengan cara dan metode yang pasti, baku, dan standar yang mengikat semua lembaga yang berwenang membentuk peraturan perundang-undangan." Hal ini di atur dalam Undang-undang Republik Indonesia No. 12 tahun 2011 tentang Pembentukan Peraturan Perundang-undangan.

Undang-undang Nomor 12 Tahun 2011 adalah dasar hukum bagi pembentukan peraturan perundang-undangan baik di tingkat pusat maupun daerah, dalam pasal 1 ayat (8) menyebutkan bahwa: Peraturan Daerah Kabupaten/Kota adalah Peraturan Perundang-undangan yang dibentuk oleh Dewan Perwakilan Rakyat Daerah Kabupaten/Kota dengan persetujuan bersama Bupati/Walikota..2

\footnotetext{
${ }^{10} \mathrm{http} / / /$ prasko17.blogspot.com/2012/08/proses-penyusunan-peraturan-daerah-perda.html, Sabtu, 16 Maret 2019, 06:56.

${ }^{11}$ Undang-Undang Republik Indonesia Nomor 12 Tahun 2011 Tentang Pembentukan Peraturan Perundang-undangan, Hal.1.

${ }^{12}$ Ibid., Hal.3.
} 
Undang-Undang ini dibentuk untuk menciptakan tertib pembentukan peraturan perundang-undangan, agar konsep dan perumusan normanya mantap, bulat, dan harmonis, tidak saling bertentangan, dan tumpang tindih satu sama lain. Melalui Undang-undang tersebut, diharapkan semua lembaga yang berwenang membentuk peraturan perundang-undangan memiliki pedoman khusus yang baku dalam prosesnya, metode dan teknik penyusunan peraturan perundang-undangan secara terencana, terpadu, dan sistematis. Selain itu, Undang-undang ini juga mengatur secara jelas, rinci mengenai proses, metode dan teknik penyusunan peraturan daerah. Ketentuan mengenai penyusunan Peraturan Daerah di atur dalam Undang-undang Nomor 12 Tahun 2011 pasal 63 yaitu; Ketentuan mengenai penyusunan Peraturan Daerah Provinsi sebagaimana dimaksud dalam Pasal 56 sampai dengan Pasal 62 berlaku secara mutatis mutandis (perubahan-perubahan yang perlu dilakukan) terhadap penyusunan Peraturan Daerah Kabupaten/ Kota.

Di dalam Peraturan Dewan Perwakilan Daerah Surakarta No.01 Tahun 2014 pasal 9 ayat (1) huruf (d) yaitu: bahwa jenis alat kelengkapan DPRD salah satunya terdiri Badan Pembentukan Peraturan Daerah yang mana Badan tersebut bersifat tetap dan di bentuk dalam rapat paripurna DPRD. Tugas Badan Pembentukan Peraturan Daerah di antaranya adalah menyusun rancangan program legislasi daerah yang memuat daftar urutan dan prioritas rancangan peraturan daerah beserta alasannya untuk setiap tahun anggaran di lingkungan DPRD diatur dalam Peraturan Dewan Perwakilan Daerah Surakarta No.01 Tahun 2014 pasal 56 huruf (a). Tentang tata cara pembentukan peraturan daerah di atur dalam pasal 110 sampai dengan pasal 117 Peraturan DPRD Surakarta No.01 Tahun 2014.

Didalam Undang-undang Republik Indonesia Nomor 32 Tahun 2009 Tentang Perlindungan dan Pengelolaan Lingkungan Hidup Pasal 1 Ayat (1) Lingkungan hidup adalah kesatuan ruang dengan semua benda, daya, keadaan, dan makhluk hidup, termasuk manusia dan perilakunya, yang mempengaruhi alam itu sendiri, kelangsungan perikehidupan, dan kesejahteraan manusia serta makhluk hidup lain, ${ }^{13}$ lingkungan hidup yang baik dan sehat merupakan hak asasi setiap warga negara Indonesia

13 Undang-Undang Republik Indonesia Nomor 32 Tahun 2009 Tentang Perlindungan Dan Pengelolaan Lingkungan Hidup, Hal.1. 
sebagaimana diamanatkan dalam Pasal 28 H Undang-undang Dasar Negara Republik Indonesia Tahun 1945, sehingga Undang-undang Republik Indonesia Nomor 32 Tahun 2009 Tentang Perlindungan dan Pengelolaan Lingkungan Hidup pasal 1, ayat (2) menyebutkan harus ada upaya sistematis dan terpadu yang dilakukan untuk melestarikan fungsi lingkungan hidup dan mencegah terjadinya pencemaran dan/atau kerusakan lingkungan hidup yang meliputi perencanaan, pemanfaatan, pengendalian, pemeliharaan, pengawasan, dan penegakan hukum. ${ }^{14}$ Pembangunan ekonomi nasional sebagaimana diamanatkan oleh Undang-undang Dasar Negara Republik Indonesia Tahun 1945 Bab XIV Tentang Perekonomian Nasional Dan Kesejahteraan Sosial, amandemen ke IV, menerangkan bahwa negara menjamin kepada setiap warga negara mengenai kesejahteraannya yaitu pada pasal 33 ayat: (4); Perekonomian nasional diselenggarakan berdasarkan prinsip pembangunan berkelanjutan dan berwawasan lingkungan .

Lingkungan hidup yang baik dan sehat merupakan hak asasi setiap warga negara Indonesia sebagaimana diamanatkan dalam Pasal 28H ayat (1) Undang-undang Dasar Negara Republik Indonesia Tahun 1945, karena melihat semakin lama kualitas lingkungan hidup yang semakin menurun telah mengancam kelangsungan perikehidupan manusia dan makhluk hidup lainnya sehingga pembangunan ekonomi nasional harus diselenggarakan berdasarkan prinsip pembangunan berkelanjutan dan berwawasan lingkungan, maka dalam pelaksaannya perlu di susun undang-undang Tentang Perlindungan dan Pengelolaan lingkungan hidup yang sungguhsungguh dan konsisten oleh semua pemangku kepentingan. Agar lebih menjamin kepastian hukum dan memberikan perlindungan terhadap hak setiap orang untuk mendapatkan lingkungan hidup yang baik dan sehat sebagai bagian dari perlindungan terhadap keseluruhan ekosistem, perlu diberlakukan Undang-undang Nomor 32 Tahun 2009 tentang perlindungan pengelolaan lingkungan hidup.

Faktor perekonomian yang berkembang pesat di wilayah Negara Kesatuan Republik Indonesia di buktikan dengan usaha-usaha yang bergerak di bidang sandang, pangan, papan, kesehatan, pariwisata dan banyak lainnya, hal ini berdampak baik bagi kesejahteraan masyarakat / penduduk Negara Kesatuan Republik Indonesia, tetapi dampak baik tersebut pasti akan diikuti

\footnotetext{
${ }^{14}$ Ibid.,
} 
oleh dampak buruk yang ditimbulkan dari berdirinya usaha-usaha tersebut diatas. Sehingga negara menjamin atas perekonomian nasional dan kesejahteraan sosial diselenggarakan berdasar atas demokrasi ekonomi salah satunya dengan prinsip berwawasan lingkungan artinya: upaya sadar dan berencana menggunakan dan mengelola sumber daya secara bijaksana dalam pembangunan yang terencana dan berkesinambungan untuk meningkatkan mutu hidup, sesuai dengan amanat Undang-undang Dasar Negara Republik Indonesia tahun 1945 Pasal 33 ayat : (4).

Undang-undang Nomor 32 tahun 2009 tentang Perlindungan dan Pengelolaan Lingkungan Hidup Pasal 1 ayat (1) menyebutkan Perlindungan dan Pengelolaan Lingkungan Hidup adalah upaya sistematis dan terpadu yang dilakukan untuk melestarikan fungsi lingkungan hidup dan mencegah terjadinya pencemaran dan/atau kerusakan lingkungan hidup yang meliputi perencanaan, pemanfaatan, pengendalian, pemeliharaan, pengawasan, dan penegakan hukum. Dalam Undang-undang Nomor 32 Tahun 2009 Tentang Perlindungan dan Pengelolaan Lingkungan Hidup Pasal 2 huruf (n) menyebutkan bahwa Perlindungan dan Pengelolaan Lingkungan Hidup berdasar atas asas otonomi daerah. ${ }^{15}$

Pembangunan nasional tidak akan lepas dari semangat otonomi daerah dalam penyelenggaraan pemerintahan Negara Kesatuan Republik Indonesia yang telah membawa perubahan hubungan dan kewenangan antara Pemerintah dan Pemerintah Daerah, termasuk di bidang perlindungan dan pengelolaan lingkungan hidup, dan untuk melaksanakan ketentuan Pasal 63 ayat (3) Undang-undang Nomor 32 Tahun 2009 Tentang Perlindungan dan Pengelolaan Lingkungan Hidup yaitu: Dalam perlindungan dan pengelolaan lingkungan hidup, pemerintah kabupaten/ kota bertugas dan berwenang menetapkan kebijakan tingkat kabupaten/kota, maka untuk memberikan kepastian hukum dalam pelestarian fungsi lingkungan hidup yaitu; rangkaian upaya untuk memelihara kelangsungan daya dukung dan daya tampung lingkungan ${ }^{16}$ kabupaten/ kota. Maka perlu landasan yang kuat tentang perlindungan dan pengelolaan lingkungan hidup dalam suatu Peraturan Daerah Tentang Perlindungan dan Pengelolaan Lingkungan Hidup.

\footnotetext{
${ }^{15}$ Undang-Undang Nomor 32 Tahun 2009 tentang Perlindungan dan Pengelolaan Lingkungan Hidup, Hal.5.

${ }_{16}$ Peraturan Daerah Surakarta No. 10 Tahun 2015, Tentang Perlindungan Dan Pengelolaan Lingkungan Hidup, Hal 4.
} 
Setiap sektor/ bidang usaha atau industri yang bergerak dalam dalam bidang pangan, sandang, papan, kesehatan, pariwisata dan yang lainnya selalu menghasilkan sisa suatu kegiatan atau usaha yang di namakan limbah, yang mana limbah tersebut akan di buang di media lingkungan hidup tempat tinggal manusia, sehingga dalam pasal 20 ayat Undang-undang Nomor 32 Tahun 2009 Tentang Perlindungan dan Pengelolaan Lingkungan Hidup mengatur bahwa:

1. Penentuan terjadinya pencemaran lingkungan hidup diukur melalui baku mutu lingkungan hidup.

2. Baku mutu lingkungan hidup meliputi:

a. baku mutu air.

b. baku mutu air limbah;

c. baku mutu air laut;

d. baku mutu udara ambien;

e. baku mutu emisi;

f. baku mutu gangguan; dan

g. baku mutu lain sesuai dengan perkembangan ilmu pengetahuan dan teknologi.

3. Setiap orang diperbolehkan untuk membuang limbah ke media lingkungan hidup dengan persyaratan:

a. memenuhi baku mutu lingkungan hidup; dan

b. mendapat izin dari Menteri, gubernur, atau bupati/walikota sesuai dengan kewenangannya.

4. Ketentuan lebih lanjut mengenai baku mutu lingkungan hidup sebagaimana dimaksud pada ayat (2) huruf a, huruf c, huruf d, dan huruf g diatur dalam Peraturan Pemerintah.

5. Ketentuan lebih lanjut mengenai baku mutu lingkungan hidup sebagaimana dimaksud pada ayat (2) huruf $b$, huruf e, dan huruf f diatur dalam peraturan menteri. ${ }^{77}$

${ }^{17}$ Undang-undang Nomor 32 Tahun 2009, Op.Cit., pasal 20. 
Salah satu upaya perlindungan dan pengelolaan lingkungan hidup yang disusun dalam Pasal 20 Undang-undang Nomor 32 Tahun 2009 di atas adalah bertujuan untuk kemaslahatan warga negara Indonesia pada khususnya.

Sesuai amanat Undang-undang Dasar 1945 Pasal 5 ayat (2) sebagaimana telah diubah dengan Perubahan Keempat Undang-undang Dasar 1945; bahwa Presiden menetapkan peraturan pemerintah untuk menjalankan undang-undang sebagaimana mestinya ${ }^{18}$, maka dalam Peraturan Pemerintah Nomor 82 Tahun 2001 Tentang Pengelolaan Kualitas Air dan Pengendalian Pencemaran Air pasal 18 ayat (3) menyebutkan bahwa wewenang Pemerintah Kabupaten/ Kota melakukan pengendalian pencemaran air pada sumber air yang berada pada Kabupaten/ Kota' ${ }^{19}$. Bahwa Peraturan Pemerintah Nomor 82 Tahun 2001 Tentang Pengelolaan Kualitas Air dan Pengendalian Pencemaran Air pasal 1 ayat (11) menyebutkan pencemaran air ialah memasuknya atau dimasukkannya makhluk hidup, zat, energi dan atau komponen lain ke dalam air oleh kegiatan manusia, sehinga kualitas air turun sampai ke tingkat tertentu yang menyebabkan air tidak dapat berfungsi sesuai dengan peruntukannya ${ }^{20}$ sehingga beban pencemaran atau unsur pencemar yang terkandung di dalam air atau air limbah harus di batasi dengan adanya baku mutu air limbah yaitu; ukuran batas atau kadar unsur pencemar dan atau jumlah unsur pencemar yang ditenggang keberadaanya dalam air limbah yang akan dibuang atau dilepas ke dalam sumber air dari suatu usaha dan atau kegiatan.21

Baku mutu air limbah di atur dalam pasal 21 ayat (1) dan (2) Peraturan Pemerintah Nomor 82 Tahun 2001 Tentang Pengelolaan Kualitas Air dan Pengendalian Pencemaran Air yaitu:

1. Baku mutu air Limbah nasional ditetapkan dengan Keputusan Menteri dengan memperhatikan saran masukan dari instansi terkait.

2. Baku mutu air limbah daerah ditetapkan dengan Peraturan Daerah Propinsi dengan ketentuan sama atau lebih ketat dari baku mutu air limbah nasional sebagaimana dimaksud dalam ayat (1).

${ }^{18}$ Undang-Undang Dasar Republik Indonesia Tahun 1945.

19 Peraturan Pemerintah Nomor 82 Tahun 2001 Tentang Pengelolaan Kualitas Air dan Pengendalian Pencemaran Air, pasal 18, ayat 3.

${ }^{20}$ Ibid., pasal 1 , ayat 11 .

${ }^{21} \mathrm{Ibid}$., ayat 15 . 
Undang-undang no 32 tahun 2014 pasal 20 ayat (5) mengamanatkan yaitu ; Ketentuan lebih lanjut mengenai baku mutu lingkungan hidup sebagaimana dimaksud pada ayat (2) huruf $b$, diatur dalam peraturan menteri, dan pelaksanaan Peraturan Pemerintah Nomor 82 Tahun 2001 Tentang Pengelolaan Kualitas Air dan Pengendalian Pencemaran Air pasal 21 ayat (1) mengamanatkan yaitu: Baku mutu air limbah nasional ditetapkan dengan Keputusan Menteri dengan memperhatikan saran masukan dari instansi terkait maka sebagai pedoman di lapangan untuk pelaksanaannya.

Peraturan perundang-undangan tentang baku mutu limbah cair telah dilaksanakan sesuai dengan amanat undang-undang tertera dalam Peraturan Menteri Lingkungan Hidup Nomor 5 Tahun 2014 Tentang Baku Mutu Air Limbah. Dalam Peraturan Menteri Lingkungan Hidup Nomor 5 Tahun 2014 Tentang Baku Mutu Air Limbah Pasal 2 huruf (a) yaitu: Peraturan Menteri ini bertujuan untuk memberikan acuan mengenai baku mutu air limbah kepada Gubernur dalam menetapkan baku mutu air limbah yang lebih ketat, sedangkan pasal 3 ayat (1) : Usaha dan/atau kegiatan yang baku mutu air limbahnya diatur dalam Peraturan Menteri, dan pasal 6 ayat (1) yaitu: Dalam hal gubernur belum melakukan kajian ilmiah dan/atau menetapkan baku mutu air limbah yang lebih spesifik dan/atau lebih ketat, bupati/ walikota dalam menerbitkan izin pembuangan air limbah ke sumber air wajib menggunakan baku mutu lebih ketat yang diperoleh dari hasil kajian dokumen lingkungan atau kajian pembuangan air limbah ke sumber air. Dalam Peraturan Menteri Lingkungan Hidup Nomor 5 Tahun 2014 Tentang Baku Mutu Air Limbah di pakai apabila Pemerintah Daerah belum menetapkan baku mutu air limbsah di daerahnya.

Untuk melaksanakan ketentuan pasal 21 ayat (2) Peraturan Pemerintah Nomor 82 Tahun 2001 Tentang Pengelolaan Kualitas Air dan Pengendalian Pencemaran Air Tentang Baku Mutu Air Limbah pasal Pasal 2 huruf (a) yaitu; Baku mutu air limbah daerah ditetapkan dengan Peraturan Daerah Propinsi dengan ketentuan sama atau lebih ketat dari baku mutu air limbah nasional, serta dalam rangka pelestarian fungsi lingkungan hidup perlu dilakukan upaya pengendalian terhadap usaha dan/atau kegiatan yang berpotensi mencemari lingkungan hidup melalui penetapan baku mutu air limbah, telah ditetapkan Peraturan Daerah Provinsi Jawa Tengah Nomor 10 Tahun 2004 tentang Baku Mutu Air Limbah. Dengan meningkatnya 
kemajuan teknologi pengelolaanair limbah dan perkembangan peraturan perundang-undangan,maka Peraturan Daerah Peraturan Daerah Provinsi Jawa Tengah Nomor 10 Tahun 2004, perlu dilakukan penyesuaian dengan menerbitkan Peraturan Daerah Provinsi Jawa Tengah Nomor 5 Tahun 2012 Tentang Perubahan Atas Peraturan Daerah Provinsi Jawa Tengah Nomor 10 Tahun 2004 Tentang Baku Mutu Air Limbah.

Di dalam Peraturan Daerah Provinsi Jawa Tengah Nomor 5 Tahun 2012 Tentang Perubahan Atas Peraturan Daerah Provinsi Jawa Tengah Nomor 10 Tahun 2004 Tentang Baku Mutu Air Limbah pasal 5 huruf (a) yaitu; Gubernur berwenang menetapkan baku mutu air limbah bagi setiap usaha dan/atau kegiatan. Kemudian dalam pasal 6 ayat (1) tentang ruang lingkupnya yaitu; Ruang lingkup penetapan baku mutu air limbah meliputi:

1. Baku mutu air limbah untuk usaha dan/atau kegiatan bagi 35 (tiga puluh lima) industri;

2. Baku mutu air limbah untuk kegiatan industri yang menghasilkan lebih dari satu jenis produk (campuran);

3. Baku mutu air limbah hotel;

4. Baku mutu air limbah rumah sakit;

5. Baku mutu air limbah bagi usaha dan/atau kegiatan pertambangan bijih besi;

6. Baku mutu air limbah bagi usaha dan/atau kegiatan minyak dan gas serta panas bumi;

7. Baku mutu air limbah bagi kawasan industri;

8. Baku mutu air limbah domestik;

9. Baku mutu air limbah untuk usaha dan/atau kegiatan yang belum ditetapkan baku mutunya;

10. Perhitungan tentang debit air limbah maksimum dan bebanpencemaran maksimum.22

${ }^{22}$ Peraturan Daerah Provinsi Jawa Tengah Nomor 5 Tahun 2012 Tentang Baku Mutu Air Limbah, pasal 6, ayat 1. 
Terakhir dalam pasal 8 Peraturan Daerah Provinsi Jawa Tengah Nomor 5 Tahun 2012 Tentang Perubahan Atas Peraturan Daerah Provinsi Jawa Tengah Nomor 10 Tahun 2004 Tentang Baku Mutu Air Limbah menyebutkan yaitu; Setiap penanggung jawab usaha dan/atau kegiatan yang membuang air limbah ke lingkungan wajib:

1. Memenuhi baku mutu air limbah sebagaimana tercantum dalam Lampiran Peraturan Daerah ini;

2. Melakukan pengolahan air limbah yang dibuang agar memenuhi baku mutu air limbah sebagaimana tercantum dalam Lampiran Peraturan Daerah ini;

3. Membuat instalasi pengolah air limbah dan sistem saluran air limbah kedap air sehingga tidak terjadi perembesan air limbah ke lingkungan

4. Memasang alat ukur debit atau laju alir limbah pada inlet instalasi

5. Pengolahan air limbah dan outlet instalasi pengolahan air limbah sertainlet pemanfaatan kembali apabila air limbah yang dihasilkan dimanfaatkan kembali;

6. Melakukan pencatatan debit harian air limbah baik untuk air limbah yang dibuang ke sumber air dan/atau laut, dan/atau yang dimanfaatkan kembali;

7. Melakukan pencatatan ph harian air limbah;

8. Tidak melakukan pengenceran air limbah ke dalam aliran buangan air limbah;

9. Melakukan pencatatan jumlah bahan baku dan produk harian senyatanya; memisahkan saluran pembuangan air limbah dengan saluran limpasan air hujan;

10. Menetapkan titik penaatan untuk pengambilan contoh uji;

11. Memeriksakan kadar parameter air limbah sebagaimana tercantum dalam Lampiran Peraturan Daerah ini secara berkala paling sedikit 1 (satu) kali dalam 1 (satu) bulan di laboratorium yang terakreditasi dan teregistrasi di Kementerian Lingkungan Hidup;

12. Menyampaikan laporan debit air limbah harian, ph harian, penggunaanbahan baku, jumlah produk harian, dan kadar parameter air 
limbah sebagaimana dimaksud dalam huruf c, huruf e, huruf g, dan huruf jsecara berkala paling sedikit 1 (satu) kali dalam 1 (satu) bulan kepada Bupati/Walikota dengan tembusan kepada Gubernur dan Menteri serta instansi lain yang terkait sesuai dengan peraturan perundang-undangan;dan

13. Melaporkan kepada Bupati/Walikota dengan tembusan kepada Gubernur dan Menteri mengenai kejadian tidak normal dan/atau keadaan daruratyang mengakibatkan baku mutu air limbah dilampaui serta rincian upaya penanggulangannya paling lama 2 X 24 jam. ${ }^{23}$

\section{B. METODE PENELITIAN}

Pendekatan penelitian menggunakan metode penelitian kualitatif. Teknik pengumpulan data dalam melakukan penelitian dalam hal ini adalah mengedepankan data skunder untuk di pelajari sesuai dengan masalah yang di teliti melalui studi kepustakaan yaitu: pengumpulan data dengan mempelajari sumber-sumber kepustakaan berupa peraturan perundangundangan.

\section{HASIL DAN PEMBAHASAN}

\section{Perundang-undangan}

Ilmu perundang-undangan adalah suatu ilmu yang berorientasi dalam hal melakukan perbuatan (dalam hal ini adalah pembentukan peraturan perundang-undangan dan bersifat normatif. Selanjutnya Burkhardt Krems dalam bukunya Maria Farida Indrati menjelaskan bahwa Ilmu Pengetahuan Perundang undangan merupakan ilmu yang interdisipliner yang berhubungan dengan ilmu politik dan sosiologi yang secara garis besar dapat dibagi menjadi dua bagian besar yaitu:

a. Teori Perundang-undangan, yang berorientasi pada mencari kejelasan dan kejernihan makna atau pengertian-pengertian dan

\footnotetext{
${ }^{23}$ Ibid., pasal 8.
} 
bersifat kognitif yaitu; berdasar kepada pengetahuan faktual yang beradasarkan pengalaman/penemuan. ${ }^{24}$

b. Ilmu Perundang-undangan, yang berorientasi pada melakukan perbuatan dalam hal pembentukan peraturan perundangundangan dan bersifat normatif.

Istilah "perundang-undangan" mempunyai dua pengertian yang berbeda, yaitu:

1) Perundang-undangan sebagai sebuah proses pembentukan atau proses membentuk peraturan-peraturan negara baik ditingkat pusat maupun di tingkat daerah; dan

2) Perundang-undangan sebagai segala peraturan negara, yang merupakan hasil proses pembentukan peraturan-peraturan baik ditingkat pusat maupun di tingkat daerah. ${ }^{25}$

Disamping itu, ada 3 (tiga) fungsi utama dari ilmu perundangundangan, yaitu:

1) Untuk memenuhi kebutuhan hukum dalam kehidupan bermasyarakat, berbangsa dan bernegara yang senantiasa berkembang;

2) Untuk menjembatani lingkup hukum adat dengan hukum yang tidak tertulis lainnya;

3) Untuk memenuhi kebutuhan kepastian hukum tidak tertulis bagi masyarakat. ${ }^{20}$

Berdasarkan uraian tersebut dapat dikatakan bahwa apabila berbicara tentang Ilmu perundang-undangan maka dalam prosesnya akan membahas pula mengenai pembentukan peraturan-peraturan negara dan sekaligus semua peraturan negara yang merupakan hasil dari pembentukan peraturan-peraturan negara baik yang ada ditingkat pusat maupun yang ada ditingkat daerah.

${ }^{24} \mathrm{https}: / /$ kbbi.web.id/empiris, Sabtu 11 Mei 2019, 17:18.

${ }^{25}$ Azis Syamsudin, Praktek dan Teknik Penyusunan Undang-Undang, (Jakarta: Sinar Grafika, 2011), hal.13.

${ }^{26}$ Ibid. 
Peraturan-peraturan negara di dalam keberlakuannya berpedoman pada asas-asas perundang-undangan. Asas dapat diartikan sebagai aksioma yang memberi jalan pemecahannya jika sesuatu aturan diperlakukan atau aturan yang mana harus diperlakukan bila terjadi bentrokan beberapa aturan dalam pelaksanaannya atau dapat diartikan sebagai suatu kesepakatan universal yang berupa pemikiran-pemikiran dasar untuk dijadikan landasan pengaturan bersama dalam membuat peraturan perundangundangan. Berdasarkan perkembangannya ada 2 (dua) jenis asas, yaitu:

a. Asas yang berlaku secara Internasional untuk membuat perundang-undangan terdapat 5 (lima) asas yaitu:

1) Lex specialis derogate legi generali (Aturan hukum yang khusus mengesampingkan aturan hukum yang umum).

2) Lex posterior derogate legi priori. (Peraturan yang lebih tinggi mengesampingkan yang rendah).

3) Lex superior derogate legi inferiori (Peraturan yang paling baru melumpuhkan peraturan yang lama).

4) Undang-undang tidak berlaku surut (Asas Non Retroaktif).

5) Undang-undang tidak boleh diganggu gugat (siapapun tidak boleh melakukan uji material atas isi undang-undang, kecuali oleh Mahkamah Konstitusi).

b. Asas yang berlaku secara Nasional

Asas-asas peraturan perundng-undangan di Indonesia yang berdasarkan ketentuan terbaru dalam pasal 5 Undang-undang Nomor 12 Tahun 2011 Tentang Pembentukan Peraturan Perundang-undangan, yaitu: Pasal 5 Undang-undang Nomor 12 Tahun 2011 Tentang Pembentukan Peraturan Perundangundangan menyebutkan asas pembentukan peraturan perundangundangan yang baik, antara lain:

1) Kejelasan Tujuan; 
Asas kejelasan tujuan adalah bahwa setiap pembentukan peraturan perundang-undangan harus mempunyai tujuan yang jelas yang hendak dicapai.

2) Kelembagaan atau pejabat pembentuk yang tepat

Asas kelembagaan atau pejabat pembentuk yang tepat adalah bahwa setiap jenis peraturan perundang-undangan harus dibuat oleh lembaga negara atau pejabat pembentuk peraturan perundang-undangan yang berwenang. peraturan perundang-undangan tersebut dapat dibatalkan atau batal demi hukum apabila dibuat oleh lembaga negara atau pejabat yang tidak berwenang.

3) Kesesuaian antara jenis, hierarki dan materi muatan;

Asas kesesuaian antara jenis, hierarki, dan materi muatan adalah bahwa dalam pembentukan peraturan perundangundangan harus benar benar memperhatikan materi muatan yang tepat sesuai dengan jenis dan hierarki peraturan perundang-undangan.

4) Dapat dilaksanakan;

Asas dapat dilaksanakan adalah bahwa setiap pembentukan peraturan perundang-undangan harus memperhitungkan efektivitas peraturan perundang-undangan tersebut di dalam masyarakat, baik secara filosofis, sosiologis, maupun yuridis.

5) Kedayagunaan dan kehasilgunaan;

Asas kedayagunaan dan kehasilgunaan adalah bahwa setiap peraturan perundang-undangan dibuat karena memang benarbenar dibutuhkan dan bermanfaat dalam mengatur kehidupan bermasyarakat, berbangsa, dan bernegara.

6) Kejelasan Rumusan;

Asas kejelasan rumusan adalah bahwa setiap peraturan perundang-undangan harus memenuhi persyaratan teknis penyusunan peraturan perundang-undangan, sistematika, pilihan kata atau istilah, serta bahasa hukum yang jelas dan 
mudah dimengerti sehingga tidak menimbulkan berbagai macam interpretasi dalam pelaksanaannya.

\section{7) Keterbukaan}

Asas keterbukaan adalah bahwa dalam pembentukan peraturan perundang-undangan mulai dari perencanaan, penyusunan, pembahasan, pengesahan atau penetapan, dan pengundangan bersifat transparan dan terbuka. Dengan demikian, seluruh lapisan masyarakat mempunyai kesempatan yang seluas-luasnya untuk memberikan masukan dalam Pembentukan Peraturan Perundang-undangan.

Suatu norma hukum memiliki masa berlaku yang relatif tergantung dari norma hukum yang lebih tinggi atau di atasnya. Sehingga apabila norma hukum di atas dihapus maka norma hukum yang di bawahnya secara otomatis terhapus. Norma dasar yang merupakan norma tertinggi dalam sistem norma tersebut tidak lagi dibentuk oleh suatu norma yang lebih tinggi lagi, tetapi norma dasar itu ditetapkan terlebih dahulu oleh masyarakat sebagai norma dasar yang merupakan gantungan bagi norma-norma yang berada di bawahnya sehingga suatu norma dasar itu dikatakan pre-supposed. ${ }^{27}$

Dalam kaitannya dengan hierarki norma hukum Hans Kelsen mengemukakan teorinya mengenai jenjang norma hukum, dimana ia berpendapat bahwa norma-norma hukum itu berjenjang-jenjang dan berlapis-lapis dalam suatu hierarki tata susunan, dimana suatu norma yang lebih rendah berlaku, bersumber, dan berdasar pada norma yang lebih tinggi, norma yang lebih tinggi berlaku, bersumber dan berdasar pada norma yang lebih tinggi lagi, demikian seterusnya sampai pada suatu norma yang tidak dapat ditelusuri lebih lanjut dan bersifat hipotesis dan fiktif, yaitu Norma Dasar (Grundnorm) ${ }^{2 .}{ }^{28}$

Selain itu dalam pembentukan peraturan perundang-undangan dikenal ada 3 (tiga) landasan teori agar suatu perundang-undangan itu baik yang diterapkan dinegara demokrasi antara lain:

${ }^{27}$ Maria Farida Indrati, Ilmu Perundang-undangan Dasar-Dasar dan Pembentukannya, Jilid I, (Yogyakarta: Kansius, 2007), hal 2-3.

${ }^{28}$ Jimly Asshiddiqie, Perihal Undang-Undang, (kota: tanpa penerbit, tanpa tahun), hal. 91. 
a. Bahwa Peraturan tersebut harus berlandaskan aspek yuridis.

Landasan yang menekankan bahwa dalam pembuatan peraturan perundang-undangan itu harus memberikan kepastian hukum seperti: ketepatan waktu, tidak ada diskriminasi. Selain itu, landasan yuridis sangat penting karena akan menunjukan adanaya kewenangan dari pembuat undang-undang, adanya hierarki (tidak bertentangan dengan peraturan yang lebih tinggi), adanya kesesuaian jenis, materi muatan yang akan diatur. Landasan yuridis menjadi dasar kewenangan pembuat peraturan perundang-undangan. Sehingga apabila pejabat atau badan hukum tidak disebutkan dalam undang-undang memiliki kewenangan membuat suatu peraturan maka pejabat atau badan hukum itu tidak berwenang untuk itu. Seperti dalam pasal 20 ayat (1) Undang-undang Dasar 1945 memberikan kewenangan kepada DPR untuk membentuk undang-undang.

b. Bahwa Peraturan tersebut harus berlandaskan aspek filosofis.

Dasar filosofis merupakan cita hukum. Atau dengan kata lain bahwa filsafat adalah pandangan hidup bangsa dan merupakan nilai-nilai moral dari suatu bangsa tersebut. Dimana dalam moral itu berisi nilai baik dan nilai buruk. Nilai baik adalah nilai yang mengandung keadilan, kebenaran, kejujuran dan semua nilai-nilai yang dianggap baik oleh masyarakat

c. Bahwa Peraturan tersebut harus berlandaskan aspek sosiologis.

Dalam membuat suatu peraturan perundang-undangan harus didasarkan pada daya guna dan hasil guna, mempertimbangkan nilai-nilai sosial yang berlaku dalam masyarakat. Peraturan yang dibuat harus berdasarkan pada keyakinan umum dan kesadaran masyarakat karenan nantinya peraturan itu akan diberlakukan kepada masyarakat

Pasal 1 ayat (13) Undang-undang Nomor 12 Tahun 2011 Tentang Pembentukan Peraturan Perundang-undangan menyatakan bahwa; Materi Muatan Perundang-undangan adalah materi yang dimuat dalam peraturan perundang-undangan sesuai dengan jenis, fungsi dan hierarki Peraturan Perundang-undangan. 
Dalam hal membuat suatu perundang-undangan terkait dengan adanya materi muatan yang akan diatur, dalam Pasal 6 Undangundang Nomor 12 Tahun 2011 Tentang Pembentukan Peraturan Perundang-undangan, menyebutkan bahwa materi muatan peraturan perundang-undangan harus mencerminkan asas:

a. Pengayoman

Asas pengayoman adalah bahwa setiap materi muatan peraturan perundang-undangan harus berfungsi memberikan pelindungan untuk menciptakan ketentraman masyarakat.

b. Kemanusiaan

Asas kemanusiaan adalah bahwa setiap materi muatan peraturan perundangundangan harus mencerminkan pelindungan dan penghormatan hak asasi manusia serta harkat dan martabat setiap warga negara dan penduduk Indonesia secara proporsional.

c. Kebangsaan

Asas kebangsaan adalah bahwa setiap materi muatan peraturan perundang-undangan harus mencerminkan sifat dan watak bangsa Indonesia yang majemuk dengan tetap menjaga prinsip Negara Kesatuan Republik Indonesia.

d. Kekeluargaan;

Asas kekeluargaan adalah bahwa setiap materi muatan peraturan perundang-undangan harus mencerminkan musyawarah untuk mencapai mufakat dalam setiap pengambilan keputusan.

e. Kenusantaraan

Asas kenusantaraan adalah bahwa setiap materi muatan peraturan perundang-undangan senantiasa memperhatikan kepentingan seluruh wilayah indonesia dan materi muatan peraturan perundang-undangan yang dibuat di daerah merupakan bagian dari sistem hukum nasional yang berdasarkan 
Pancasila dan Undang-undang Dasar Negara Republik Indonesia Tahun 1945

f. Bhineka Tunggal Ika

Asas bhinneka tunggal ika adalah bahwa materi muatan peraturan perundang-undangan harus memperhatikan keragaman penduduk, agama, suku dan golongan, kondisi khusus daerah serta budaya dalam kehidupan bermasyarakat, berbangsa, dan bernegara.

g. Keadilan

Asas keadilan adalah bahwa setiap materi muatan peraturan perundang-undangan harus mencerminkan keadilan secara proporsional bagi setiap warga negara.

h. Kesamaan kedudukan dalam hukum dan pemerintahan

Asas kesamaan kedudukan dalam hukum dan pemerintahan adalah bahwa setiap materi muatan peraturan perundangundangan tidak boleh memuat hal yang bersifat membedakan berdasarkan latar belakang, antara lain, agama, suku, ras, golongan, gender, atau status sosial.

i. Ketertiban dan kepastian hukum

Asas ketertiban dan kepastian hukum adalah bahwa setiap materi muatan peraturan perundang-undangan harus dapat mewujudkan ketertiban dalam masyarakat melalui jaminan kepastian hukum

j. Keselarasan, Keserasian dan Keseimbangan

Asas keseimbangan, keserasian, dan keselarasan adalah bahwa setiap materi muatan peraturan perundang-undangan harus mencerminkan keseimbangan, keserasian dan keselarasan, antara kepentingan individu, masyarakat dan kepentingan bangsa dan negara. ${ }^{29}$

29 Undang-Undang Nomor 12 Tahun 2011 Tentang Pembentukan Peraturan PerundangUndangan, Pasal 6. 
Indonesia adalah negara hukum, sehingga konsekuensi dari negara hukum bahwa harus mencakup elemen penting seperti : adanya perlindungan Hak Asasi Manusia, pembagian dan pemisahan kekuasaan pemerintahan berdasarkan dengan undang-undang.

Terkait dengan pemerintahan, berdasar dengan undang-undang maka segala tindakan yang dilakukan oleh pemerintah harus berdasarkan hukum. Didalam Undang-undang Nomor 12 Tahun 2011 Tentang Pembentukan Peraturan Perundang-undangan pasal 1 ayat (1) Pembentukan peraturan perundang-undangan adalah pembuatan Peraturan perundang-undangan yang mencakup tahapan perencanaan, penyusunan, pembahasan, pengesahan atau penetapan, dan pengundangan..$^{30}$ Sebagaimana ketentuan dalam pasal 7 ayat 1 Undang-undang Nomor 12 Tahun 2011 Tentang Pembentukan Peraturan Perundang-undangan dan Ketetapan MPR No.III/MPR/2000 Tentang Sumber Hukum dan Tata Urutan Peraturan Perundang-undangan jenis dan hierarki perundangundangan.

Berbicara jenis peraturan perundang-undangan, kita perlu pemahanan lebih dalam terhadap pembentukan peraturan perundangundangan, dimana yang dimaksud didalamnya lebih menekankan pada ketentuan hierarki atau perjenjangan setiap jenis peraturan perundang-undangan yang didasarkan pada asas bahwa peraturan perundang-undangan yang lebih rendah tidak boleh bertentangan dengan peraturan perundang-undangan yang lebih tinggi. Berdasarkan perkembangannya Indonesia mempunyai 2 (dua) landasan hukum perundang-undangan, yaitu:

a. Ketetapan MPR No.III/MPR/2000 Tentang Sumber Hukum dan Tata Urutan Peraturan Perundang-undangan:

1) Undang-undang Dasar Negara Republik Indonesia Tahun 1945 ;

2) Ketetapan Majelis Permusyawaratan Rakyat;

3) Undang-undang;

\footnotetext{
${ }^{30}$ Ibid., Hal.2.
} 
4) Peraturan pemerintah Pengganti Undang-undang;

5) Peraturan Pemerintah;

6) Keputusan Presiden; dan

7) Peraturan Daerah.

b. Undang-undang Nomor 12 Tahun 2011 Tentang Pembentukan Peraturan Perundang-undangan:

1) Undang-undang Dasar Negara Republik Indonesia Tahun 1945

2)Ketetapan Majelis Permusyawaratan Rakyat;

3)Undang-undang/ Peraturan Pemerintah Pengganti Undangundang;

4)Peraturan Pemerintah; Peraturan Presiden;

5)Peraturan Daerah Provinsi; dan

6)Peraturan Daerah Kabupaten/Kota.

\section{Pembentukan Peraturan Daerah.}

Setiap jenis peraturan perundang-undangan tersebut di atas memiliki fungsi, tujuan, teknik pembentukan yang berbeda-beda, karena dalam pemakaiannya itu pun berbeda. Salah satunya adalah Peraturan Daerah Kabupaten/ Kota dalam tata urutan perundangan Indonesia terdapat Peraturan Daerah (Perda) dan Proses Penyusunan Peraturan Daerah melalui tahapan sebagai berikut :

1. Tahapan Pengajuan Peraturan Daerah (Perda)

Pada tahap ini, pengajuan rancangan peraturan daerah dapat dilakukan oleh Pemerintah Daerah maupun oleh DPRD. Pengajuan Rancangan Perda oleh Kepala Daerah proses pengajuan rancangan peraturan daerah dari kepala daerah adalah sebagai berikut:

a. Konsep rancangan peraturan daerah disusun oleh dinas yang berkaitan dengan Perda yang dibuat. 
b. Konsep rancangan Perda yang telah disusun diajukan kepada biro hukum untuk dilakukan pemeriksaan secara teknis.

c. Biro hukum selanjutnya mengundang dinas yang mengajukan rancangan Perda untuk melakukan penyempurnaan konsep rancangan Perda yang bersangkutan.

d. Biro hukum menyerahkan hasil penyempurnaan rancangan Perda kepada kepala daerah untuk disetujuinya.

e. Konsep rancangan Perda yang telah disetujui oleh kepala daerah berubah menjadi rancangan peraturan daerah.

f. Rancangan peraturan daerah kemudian oleh kepala daerah disampaikan kepada ketua DPRD yang disertai dengan surat pengantar untuk memperoleh persetujuan dari DPRD.

2. Pengajuan Rancangan Peraturan Daerah oleh DPRD, proses pengajuan Rancangan Peraturan Daerah oleh DPRD adalah sebagai berikut:

a. Usulan rancangan peraturan daerah dapat diajukan oleh sekurang-kurangnya lima anggota DPRD.

b. Usulan rancangan peraturan daerah tersebut disampaikan kepada pimpinan DPRD untuk dibahas dalam sidang paripurna DPRD.

c. Pembahasan usulan rancangan peraturan daerah dalam sidang paripurna DPRD dilakukan oleh anggota DPRD bersama kepala daerah.

3. Tahap Pembahasan dalam Sidang DPRD, setelah proses pengajuan tersebut di atas, akan dilakukan pembahasan rancangan peraturan daerah melalui empat tahap sebagai berikut:

a. Tahap Pertama

Pada tahap ini dilakukan pembahasan rancangan peraturan daerah dalam sidang paripurna DPRD. Rancangan Perda yang datang dari kepala daerah, penyampaiannya dilakukan oleh kepala daerah, sedang yang datang dari DPRD penyampaiannya dilakukan oleh pimpinan gabungan komisi. 
b. Tahap Kedua

Pada tahap ini adalah acara pemandangan umum. Pemandangan umum tentang rancangan Perda yang datang dari kepala daerah dilakukan oleh anggota fraksi, dan kepala daerah yang memberikan jawaban atas pemandangan umum tersebut. Sebaliknya, untuk rancangan Perda dari DPRD, pemandangan umum disampaikan oleh kepala daerah dan DPRD memberikan jawaban atas pendapat kepala daerah.

c. Tahap Ketiga

Pada tahap ini adalah kegiatan rapat komisi atau gabungan komisi yang dihadiri oleh kepala daerah. Tujuan dalam kegiatan rapat ini adalah memperoleh kesepakatan tentang rancangan Perda antara kepala daerah dan DPRD.

d. Tahap Keempat.

Kegiatan dalam tahap keempat adalah sidang paripurna untuk mengambil keputusan dan persetujuan DPRD atas rancangan Perda. Setelah diputuskan dan disetujui, maka rancangan Perda ditetapkan dan ditanda tangani oleh kepala daerah dan DPRD. Kemudian dilanjutkan dengan pengumuman peraturan daerah pada lembaran daerah. ${ }^{31}$

\section{Pembentukan Peraturan Daerah Surakarta No. 10 Tahun 2015 Tentang Perlindungan dan Pengelolaan Lingkungan Hidup}

Perlindungan dan Pengelolaan Lingkungan Hidup di sebuah Pemerintahan Daerah harus dilaksanakan sesuai dengan amanat Undang-undang Nomor 32 Tahun 2009 Tentang Perlindungan dan Pengelolaan Lingkungan Hidup khususnya pasal 63 ayat (3) huruf (a) yaitu ; Dalam perlindungan dan pengelolaan lingkungan hidup, pemerintah kabupaten/kota bertugas dan berwenang menetapkan kebijakan tingkat kabupaten/kota, maka dalam hal ini seluruh pemerintah kabupaten/kota di wilayah Negara Kesatuan Republik Indonesia mempunyai hak dan kewajiban untuk menyusun suatu

\footnotetext{
${ }^{31} \mathrm{http}: / /$ prasko17.blogspot.com/2012/08/proses-penyusunan-peraturan-daerah-perda.html, Sabtu, 16 Maret 2019, 06:56.
} 
perundang-undangan yang mengatur Tentang Perlindungan dan Pengelolaan Lingkungan Hidup, termasuk di dalamnya adalah Pemerintah Daerah Surakarta, tanpa adanya landasan hukum yang kuat maka perlindungan dan pengelolaan lingkungan hidup tidak akan berjalan sesuai dengan apa yang di harapkan. Dalam hal ini pemerintah daerah Surakarta telah menyusun sebuah Peraturan Daerah Surakarta No. 10 Tahun 2015 Tentang Perlindungan dan Pengelolaan Lingkungan Hidup sebagai tindak lanjut dari pelaksanaan pasal 63 ayat (3) huruf (a) Undang-undang Nomor 32 Tahun 2009 Tentang Perlindungan dan Pengelolaan Lingkungan Hidup.

Peraturan Daerah Surakarta No. 10 Tahun 2015 Tentang Perlindungan dan Pengelolaan Lingkungan Hidup dalam penyusunannya harus sesuai dengan heirarki perundang-undangan yang berlaku di wilayah Negara Kesatuan Republik Indonesia yang notabene adalah Negara Hukum. Di dalam pelaksanan pembentukan Peraturan Daerah Surakarta No. 10 Tahun 2015 Tentang Perlindungan dan Pengelolaan Lingkungan Hidup, berdasarkan tahapan-tahapan yang mana sudah di atur dalam Undang-undang Republik Indonesia No. 12 tahun 2011 tentang Pembentukan Peraturan Perundang-undangan.

Pemerintah Daerah Surakarta adalah sebuah daerah otonom di wilayah Indonesia yang mempunyai kewenangan untuk mengatur dan mengurus rumah tangganya sendiri, harus diletakkan dalam kerangka negara kesatuan. Sehingga dalam penyusunan Peraturan Daerah tersebut harus sesuai dengan undang-undang, tugas dan kewenangan sebuah pemerintah daerah. Peraturan DPRD Kota Surakarta No. 01 Tahun 2014 tentang Tata Tertib DPRD Kota Surakarta mengatur tentang pembentukan Peraturan Daerah Kota Surakarta sebagaimana dalam pasal 2 yaitu: DPRD mempunyai fungsi pembentukan Perda, fungsi dalam pembentukan Perda di jalankan dalam rangka representasi dari masyarakat di daerah dan dalam rangka melaksanakan fungsinya DPRD menjaring aspirasi masyarakat. 


\section{Peraturan Daerah Surakarta No. 10 Tahun 2015 Tentang Perlindungan dan Pengelolaan Lingkungan Hidup Pasal 11 Ayat (1).}

Sesuai dengan kewenangan Pemerintah Daerah Surakarta dalam menyusun Peraturan Daerah Surakarta No. 10 Tahun 2015 Tentang Perlindungan dan Pengelolaan Lingkungan Hidup, di dalamnya memuat satu pasal tentang siapa yang berkewajiban mengolah limbah cair yang di hasilkan oleh suatu perusahaan atau kegiatan, yaitu pasal 11 ayat (1) yang berbunyi: "Setiap penanggung jawab usaha dan/atau kegiatan usaha yang menghasilkan air limbah wajib melakukan pengolahan limbahnya sendiri”. Di dalam penjelasan atas Peraturan Daerah Surakarta No. 10 Tahun 2015 pasal 11 ayat (1) cukup jelas, ini berarti bahwa setiap orang yang bertanggung jawab dalam suatu usaha atau kegiatan yang menghasilkan air limbah wajib mengolah limbah tersebut secara mandiri sesuai dengan baku mutu air limbah industri yang dihasilkannya. Kemudian usaha atau kegiatan yang mempunyai kewajiban terhadap pengolahan air limbahnya adalah usaha atau kegiatan usaha yang berbadan hukum, sebab bila di lihat dari pasal 11 ayat (2) Peraturan Daerah Surakarta No. 10 Tahun 2015 Tentang Perlindungan dan Pengelolaan Lingkungan Hidup adalah : Pemerintah Daerah bertanggungjawab menyediakan sarana dan prasara pengelolaan air limbah yang di hasilkan dari usaha kecil dan/atau air limbah rumah tangga.

Baku mutu air limbah di atur dalam pasal 21 ayat (2) Peraturan Pemerintah Nomor 82 Tahun 2001 Tentang Pengelolaan Kualitas Air dan Pengendalian Pencemaran Air pasal 21 ayat (2) yaitu: Baku mutu air limbah daerah ditetapkan dengan Peraturan Daerah Propinsi dengan ketentuan sama atau lebih ketat dari baku mutu air Limbah nasional, telah di susun oleh pemerintah Daerah Provinsi dengan Peraturan Daerah Provinsi Jawa Tengah Nomor 5 Tahun 2012 Tentang Perubahan Atas Peraturan Daerah Provinsi Jawa Tengah Nomor 10 Tahun 2004 Tentang Baku Mutu Air Limbah.

Sedangkan sebagai acuan untuk pelaksanaa selanjutnya Peraturan Daerah Peraturan Daerah Surakarta No. 10 Tahun 2015 pasal 11 ayat (1) dalam pelaksanaanya di atur dalam Peraturan 
Menteri Lingkungan Hidup Republik Indonesia Nomor 5 Tahun 2014 tentang Baku Mutu Air Limbah Pasal 5 yaitu: Terhadap baku mutu air limbah yang ditetapkan oleh gubernur, bupati/walikota wajib menggunakannya dalam menerbitkan izin pembuangan air limbah ke sumber air, kecuali diperoleh baku mutu lain yang lebih ketat dari hasil kajian dokumen lingkungan atau kajian pembuangan air limbah ke sumber air. Ini berarti bahwa baku mutu limbah cair di Kota Surakarta mengacu pada baku mutu limbah cair yang sudah ditetapkan oleh Pemerintah Daerah Provinsi Jawa Tengah.

\section{KESIMPULAN}

Pelaksanaan pembentukan Peraturan Daerah Surakarta No.10 Tahun 2015 Tentang Perlindungan dan Pengelolaan Lingkungan Hidup di Surakarta, telah sesuai dengan peraturan undang-undang yang berlaku di Negara Kesatuan Republik Indonesia. Kelebihan yaitu; sangat membantu Pemerintah Kota Surakarta dalam melestarikan fungsi lingkungan hidup, dan mempunyai kelemahan yaitu; bahwa pasal ini dalam penjelasannya belum ada tentang penanggung jawab jenis kegiatan/ usaha yang mana yang wajib mengolah limbah cairnya, karena ternyata penanggung jawab kegiatan/ usaha yang berbadan hukumlah yang wajib mengolah air limbahnya sendiri, sedangkan penanggungjawab usaha kecil dan air limbah rumah tangga sudah di atur pada pasal 11 ayat (2). 


\section{REFERENSI}

\section{Buku}

Asshiddiqie, Jimly, tanpa tahun, Perihal Undang-Undang, tanpa penerbit dan kota

Assiddiqqie, Jimly, 2006, Hukum Acara Pengujian Undang-Undang, Konstitusi Pers.

Kansil, C.S.T, Pokok-Pokok Pemerintahan Daerah, Aksara Baru, Jakarta,1979

Indrati, Maria Farida, Ilmu Perundang-undangan Dasar-Dasar dan Pembentukannya, Jilid I, Kansius, Yogyakarta, 2007.

Fauzan, Muhammad, Hukum Pemerintahan Daerah (Kajian Tentang Hubungan Keuangan Antara Pemerintah Pusat dan Daerah), STAIN Press, Purwokerto, 2002.

Marbun, B.N, DPRD Pertumbuhan, Masalah dan Masa Depannya, Jakarta, Ghalia Indonesia,1983

Syamsudin, Azis, 2011, Praktik dan Teknik Penyusunan Undang-Undang, Sinar Grafika, Jakarta

Widjaja, H.A.W, Penyelenggaraan Otonomi di Indonesia, PT Raja Grafindo Persada, Jakarta, 2005

\section{Perundang-undang}

Undang-undang Republik Indonesia Nomor 32 Tahun 2009 Tentang Perlindungan dan Pengelolaan Lingkungan Hidup.

Undang-undang Republik Indonesia Nomor 12 Tahun 2011 Tentang Pembentukan Peraturan Perundang-Undangan.

Undang-undang Republik Indonesia Nomor 23 Tahun 2014 Tentang Pemerintahan Daerah.

Peraturan Pemerintah Nomor 82 Tahun 2001 Tentang Pengelolaan Kualitas Air dan Pengendalian Pencemaran Air. 
Peraturan Pemerintah Nomor 101 Tahun 2014 Tentang Pengelolaan Limbah Bahan Beracun dan Berbahaya.

Peraturan Menteri Lingkungan Hidup No: 5 Tahun 2014 Tentang Baku Mutu Air Limbah.

Peraturan Daerah Surakarta No. 10 Tahun 2015, Tentang Perlindungan dan Pengelolaan Lingkungan Hidup.

\section{Internet}

Blog Pendidikan Indonesia, http://www.sarjanaku.com/2011/06/teknikanalisis-data.html, Kamis, 12 Oktober 2018, 19.00.

https://id.wikipedia.org/wiki/Pembangunan berkelanjutan, Jum'at, 13 Oktober 2018, 09:45.

https://kbbi.web.id/empiris, Sabtu 11 Mei 2019, 17:18.

https://kbbi.web.id/tinjau, Jum'at, 17/Mei/2019, 60:56.

https://kbbi.web.id/yuridis, Jum'at, 17/Mei/2019, 60:56.

http://prasko17.blogspot.com/2012/08/proses-penyusunan-peraturan-daerahPerda.html. Sabtu, 16 Maret 2019, 06:56.

https://www.bacaanmadani.com/2017/01/ayat-ayat-al-quran-tentangmenjaga.html, Sabtu, 16 Maret 2019, 06:56.

Jenis Metode Penelitian Kualitatif - Pendekatan dan Karakteristiknya https://pakarkomunikasi.com/jenis-metode-penelitian-kualitatif, Jum'at, 13 Oktober 2018, 10.00 .

Sidik, Maulana, "Buku Ekosistem Untuk Umum", https://maulanasidik05.wordpress.com/2015/01/09/buku-ekosistemuntuk-umum/. Hal.3. Kamis, 12 Oktober 2018, 13.00.

Subagia, Wijat, http://wijatsubagia.blogspot.co.id/2013/06/normal-0-falsefalse-false-in-x-none-x.html.Jum'at, 13 Oktober 2018, 09.40.

Wikipedia bahasa Indonesia, ensiklopedia bebas, https://id.wikipedia.org/wiki/Hipotesis. Kamis,12 Oktober 2018, 19.00. 